\title{
Exit, Voice, Loyalty ... or Deliberate Obstruction? Non-Collective Everyday Resistance under Oppression.
}

\author{
Stephanie Dornschneider
}

\begin{abstract}
In highly oppressive environments, collective resistance is very costly. Non-collective resistance constitutes a less risky alternative. Focusing on a particular oppressed setting, the Occupied Palestinian Territories, I identify everyday forms of non-collective resistance: signaling, persevering, eschewing, and coping. Characterized by low visibility and targeting political goals indirectly, these activities have not yet been recognized as forms of resistance. However, they constitute important resistance efforts that deliberately obstruct oppressive regimes. These efforts show that individuals who are not visibly resisting their rulers cannot be assumed to be loyal or to suffer from a barrier of fear, as often suggested by theories in politics. They also offer an important addition to theories that identify violence as a common response to oppression, suggesting that peaceful non-collective activities constitute an everyday alternative.
\end{abstract}

A large body of literature is dedicated to the study of collective forms of resistance (Gurr 1970; Sharp 1973; McAdam, Tarrow, and Tilly 2001; Tilly 2003; van Zomeren, Postmes, and Spears 2008; Chenowetz and Stephan 2011). In oppressive environments, however, collective resistance is highly risky and not usually the preferred channel of political opposition (Scott 1985, 1990; Bayat 2000). Instead, dissidents in such settings are known to engage in non-collective resistance, which targets regimes indirectly and is therefore less visible to the authorities. Limiting possibilities of government retaliation, this type of resistance has long-term

A list of permanent links to Supplemental Materials provided by the authors precedes the References section.

\section{Stephanie Dornschneider $($ is Assistant Professor in the} School of Politics and International Relations at University College Dublin (stephanie.dornschneider@ucd.ie).Her research combines qualitative and computational methods to explore violent and nonviolent resistance in the Middle East, focusing on the cognitive processes underlying this behavior. She is the author of Whether to Kill: The Cognitive Maps of Violent and Nonviolent Individuals (University of Pennsylvania Press, 2016) and Hot Contention, Cool Abstention: Positive Emotions and Protest Behavior During the Arab Spring (Oxford University Press, 2021). Her research has appeared in journals including the Journal of Conflict Resolution and Cognitive Science. effects on the preservation of oppressed groups and the promotion of their political aims (Scott 1985, 1987).

While the presence of non-collective resistance is well established, I present its various shapes in an oppressive environment. This variety remains less explored by studies in the field of politics due to a disproportional interest in collective resistance, and especially its violent forms, as well as the difficulty of observing non-collective behavior in oppressive settings. Based on ethnographic field research in the Occupied Palestinian Territories, I identify peaceful, everyday forms of non-collective resistance: signaling, persevering, eschewing, and coping. These behaviors can be classified as resistance because they challenge political power by deliberately obstructing oppressive regimes (cf. Sharp 1973; Foucault 1982). The proposed classification contributes to the extensive literature on power, resistance, and their complex interrelations (Foucault 1966; Abu-Lughod 1990; Scott 1985, 1990; Mitchell 1990; Wedeen 1999, 2019; Mahmood 2011). Although its categories refer to known behaviors in the fields of psychology and international relations, they have not yet been recognized as particular forms of resistance.

Resistance in oppressive settings has often been conceptualized by Hirschman's framework of "voice" and "exit" (Hirschman 1993). Accordingly, individuals have three options: to voice their discontent, to emigrate, or to quietly tolerate their situation, which indicates a certain degree of loyalty (Hirschman 1993). Since most people living under oppression do not opt for voice or exit, they are often assumed to display a certain level of loyalty to the regime. 
However, the following analysis shows that rather than quietly tolerating their situation, individuals may consider the costs of voice and exit too high, and resist their regimes through the exercise of signaling, persevering, eschewing, and coping. These efforts add to known transgressive practices of individuals under oppression (Wedeen 1999; Scott 1990; Siegman 2020).

Signaling obstructs regimes by communicating information that challenges "hegemonic narratives" reproducing existing power relations (Ewick and Silbey 1995). Signaling targets other oppressed individuals and outsiders not involved in the oppression. It can support the development of collective resistance by strengthening the identity of the oppressed (Simon and Klandermans 2001) or creating solidarity with the victims among outsiders (Dornschneider 2019a). Signaling is a form of communication that is well known in the study of international relations (Fearon 1994; Morrow 1999; Hollyer and Rosendorff 2011; Weiss 2013; McManus 2018), but not usually related to individual dissident behavior.

Persevering in their livelihoods in spite of severe oppression, individuals moreover obstruct regime efforts to expel them. Persevering includes mundane activities, such as going to work, as well as life-changing behavior, such as having a baby. In the psychology literature, perseverance is known to be an important contributor to individual achievement in open societies (Duckworth et al. 2007; Williams and DeSteno 2008). I show that perseverance may also constitute a form of non-collective resistance in oppressed societies, consistent with existing research on women in Palestine (Richter-Devroe 2018).

While persevering in activities considered to be safe, individuals eschew other activities considered more risky, such as confronting state authorities. Eschewing obstructs regimes by making it harder to recognize and punish noncollective resistance efforts. The combined use of persevering and eschewing shows that individuals carefully calculate the costs and benefits of their behavior (cf. Popkin 1979). While activists engaging in collective resistance are known for such calculations (Lohmann 1993; Kalyvas 2006; Chenowetz and Stephan 2011), I show that this deliberation also occurs in non-collective forms of resistance, building on existing work on the rationale of noncollective behavior in rural societies (Popkin 1979).

To resist the distress inflicted on them through oppression, individuals apply coping, a well-known concept from psychology (Lazarus and Folkman 1984; Roth and Cohen 1986; Skinner et al. 2003; Carver and Connor-Smith 2010). Their coping efforts consist of self-soothing activities, such as sports or the arts, which are known to reduce distress, and strengthen individuals to stay calm or find meaning in stressful situations (Carver and Connor-Smith 2010; Lazarus 2006). Coping obstructs regimes by limiting the effect of the oppression, and, by extension, regime control over the individual. Research often suggests that high levels of distress are connected to frustration and violence (Dollard et al. 1939; Berkowitz 1989), particularly in oppressive environments (Gurr 1970; Khashan 2003), including Palestine (Barber 2001; Bloom 2004; Jaeger and Paserman, 2006; Hirsch-Hoefler et al. 2016). By contrast, I identify peaceful coping activities.

The proposed classification is obtained from ethnographic interviews with Palestinians from Bethlehem, Hebron, Ramallah, and East Jerusalem (refer to the online appendix). While the methodological steps adopted by the interview analysis have been published elsewhere (Dornschneider 2019b), I focus on the substantial findings through identifying the different forms of noncollective everyday resistance.

\section{The Logic of Non-Collective Resistance Under Oppression}

Non-collective resistance is performed individually rather than in groups. ${ }^{1}$ A large body of literature is dedicated to its study, with an emphasis on resistance targeting "horizontal oppression" in day-to-day interactions with fellow citizens (e.g. Popkin 1979; Scott 1985, 1990; Abu-Lughod 1990) as opposed to "vertical oppression" exercised by political regimes and their representatives or followers (e.g., Wedeen 1999, 2019; Siegman 2020). ${ }^{2}$ This literature has identified numerous non-collective resistance efforts, including feigned ignorance, evasion, or sabotage ("weapons of the weak," see Scott 1985), or the illegal acquisition of basic life necessities, such as land for shelter, informal jobs, or public space ("quiet encroachment", see Bayat 2000). These efforts often consist of everyday activities, which are integrated into social life $^{3}$ and focus on "unspoken" rather than "formal" gains (Vinthagen and Johansson 2013; cf Scott 1985, 33).

Individuals in environments characterized by vertical oppression are often linked to non-resisting behaviors like false compliance or dissimulated loyalty (Kuran 1991; Wedeen 1999). However, research has shown that they do engage in resistance, including non-collective efforts. Humor and playful antagonism are known everyday examples of such behavior (e.g., Siegman 2020). Associated with amusement, this type of resistance is often tolerated and poses lowered risks for the individuals who engage in it (Wedeen 1999; Sorensen 2008). Another example is individualized noncompliance, such as feigned illness or ignoring demands, which may seem "innocuous" (Szalontai and Choi 2014, 67), but nevertheless heightens risks (cf. Malseed 2009). Defection has also been considered an example, though it is not an everyday behavior (cf. Fahy 2015).

Although known to be exercised individually, these behaviors are also performed in groups, and their collective performances have often received special attention (e.g., Wedeen 1999; Sorensen 2008; Malseed 2009; Hirschman 1993). Collective forms of resistance tend to draw more interest in the literature, ${ }^{5}$ because they are widely believed 
to be more effective than their non-collective counterparts, in part due to cascading effects when a critical mass has been reached (Granovetter 1978; Kuran 1991).

In highly oppressive settings, non-collective resistance may nevertheless be the only available option (Scott 1985, 1987). The main advantage of non-collective resistance in these settings is its comparatively low visibility, which may limit governmental retaliation and preserve a platform to exercise dissent on a small scale. By contrast, collective resistance is known to limit retaliation by creating risks for the government, such as shifting loyalties inside the regime or international condemnation (Chenowetz and Stephan 2011, 11). However, to impose these risks on a government, a resistance movement needs to pose a visible and credible challenge to the regime. This condition is typically not achieved in highly oppressive settings, where regimes prevent the growth of large-scale movements by systematically persecuting and severely punishing political opponents (cf. Pearlman 2016; Dornschneider 2019a).

Although performed individually, non-collective resistance benefits both individuals and collectives (Popkin 1979). Associated with changes that "help bring the system down" (Scott 1987, 452), it is performed widely (Rowbotham 1998; Sullivan 2003; Alawattage and Wickramasinghe 2009; Rao and Dutta 2012; Gillespie 2017; Lilja et al. 2017; Asgari and Sarikakis 2019; Tsai and Lin 2019). In the Occupied Palestinian Territories, non-collective resistance is understudied due to extensive collective resistance. However, given the lack of success of collective resistance and its high risks, many Palestinians choose non-collective resistance instead.

\section{Exit, Voice, Loyalty ... or Obstruction?}

In the political science literature, individuals under oppressive regimes tend to be categorised as either supporting (Hellmeier and Weidmann 2020) or justifying (Jost, Banaji and Nosek 2004) the regime; co-opted into the regime (Bueno de Mesquita et al. 1999; Yom and Gaus 2012; Gerschewski 2013); publicly opposing the regime (Chenoweth and Stepan 2011); or quietly enduring the regime. The literature has made several assumptions about individuals in the last category.

Some authors assume these individuals to dislike their regimes but suffer from a "barrier of fear" (Hinnebusch 2012, 104; Weyland 2012, 926; also see Makiya 1998). Research in psychology has shown that fear is an emotion that pushes individuals to make pessimistic risk estimates together with risk averse decisions (Lerner and Keltner 2001). In the protest literature, fear is treated as an emotion that prevents individuals from participating in resistance, and that needs to be overcome for the pursuit of political goals (Sharp and Safieh 1987, 20; Kuran 1991; Jasper 1998; van Troost, van Stteckelenburg, and Klandermans 2013; Pearlman 2016). Accordingly, individuals who are not visibly opposing or supporting their regimes are viewed as passive victims of their oppressive surroundings.

Other authors assume that individuals in the last category display a certain degree of loyalty to their oppressive rulers (Hirschman 1993; Pfaff and Kim 2003). The underlying theory of this literature was originally developed to understand consumer behavior in market situations (Hirschman 1970): When encountering a product of poor quality, consumers have three options: asking for a better product- "voice" — opting out and embracing alternatives - "exit" - or tolerating the situation while waiting for improvement- "loyalty." Numerous later applications of the theory have focused on the subject of political resistance (Hirschman 1993; Sverke and Hellgren 2001; Pfaff and Kim 2003; Dowding et al. 2000; Colomer 2000; Lagerkvist 2015; Montanaro 2019). In this literature, "voice" is typically associated with protest, although it includes other forms of opposition that are performed in public and that visibly target regimes. By contrast, "exit" is typically associated with emigration, which drains the state of its human capital. Individuals who are not exercising "voice" or "exit" are treated as loyal to the regime. The following analysis shows that individuals who do not exercise "voice" or "exit" may deliberately obstruct their regimes instead of actively tolerating or passively enduring them. As opposed to "voice," signaling, persevering, eschewing, and coping target oppressive regimes indirectly and less visibly.

\section{The Setting}

Characterized by a long history of oppression, the Occupied Palestinian Territories are a well-known setting of collective resistance (e.g., Darweish and Rigby 2015). However, not even mass uprisings with unprecedented numbers of participants or peace treaties backed by foreign players have translated into long-term improvement of Palestinian life on the ground. Today, the Occupied Territories remain a highly oppressed setting under Israeli military occupation (Human Rights Watch 2019; Freedom House 2020). ${ }^{6}$ Walled off from Israel by a barrier that spans more than $700 \mathrm{~km}, 60 \%$ of the Occupied Territories are under full Israeli control, including roads connecting Palestinian towns (Human Rights Watch 2019).

Palestinians in the Occupied Territories are moreover subject to Israeli settler colonialism (Veracini 2013). In 2019, there were 642,867 Jewish settlers (Human Rights Watch 2019), and their number continues to rise. In 2017, the annual growth number of settlers was almost twice that of Israel (Btselem 2019). During the first nine months of 2019, Israel approved 5,995 housing units in the West Bank (an increase of 6.7\% from 2018; Human Rights Watch 2019). Simultaneously, an increasing number of Palestinian homes was demolished in areas of the West Bank under Israeli control as well as East Jerusalem (Human Rights Watch 2019). 
In East Jerusalem, only $16.5 \%$ of the construction permits issued between 1991 and 2019 were designated to Palestinian structures, while $45 \%$ of permits issued for Israeli constructions were in areas that were annexed by Israel in 1967 (Peace Now 2019). Consistent with Trump's "Peace Plan," which recognizes Jerusalem as Israel's undivided capital (White House 2020), approval of Israeli housing units in East Jerusalem has increased by 58\% since Trump's election (Peace Now 2019). Israel furthermore revoked the residency status of at least 14,595 Palestinians who lived in Jerusalem between 1967 and 2016 (Human Rights Watch 2017).

The Palestinian economy remains highly dependent on Israel (Farsakh 2016; El Zein 2017; also see Haddad 2016). Checkpoints and closure policies have severely limited competitiveness. Production has been shrinking and absorbing a growing labour force is a major challenge (World Bank 2019b). In 2019, 24\% of the population lived below 5.5 USD per day (World Bank 2019a). Public opinion polls show that views about the Palestinian economic situation are generally negative, with $76 \%$ considering it bad or very bad (Arab Barometer 2019).

Palestinians have often engaged in collective resistance to confront Israeli oppression. Although exercised by a tiny minority, violent resistance has received extensive attention in academic research (Barber 2001; Khashan 2003; Bloom 2004; Jaeger and Paserman 2006; Hirsch-Hoefler et al. 2016), media coverage (e.g., Economist 2018; New York Times 2020; BBC 2020), and public opinion polls (Pew Research Centre 2014; Palestinian Centre for Policy and Survey Research 2015). In particular, Hamas' armed wing has often drawn interest, although research has shed a more nuanced light on variations in the movement's resistance strategies (Abu-Amr 1993; Hroub 2006; Mishal and Sela 2006; Gunning 2007; MiltonEdwards and Farrell 2010; Baconi 2018).

By contrast, public opinion polls have shown that Palestinians oppose violence when diplomacy is considered effective (Shikaki 2006). Numerous studies dedicated to nonviolent forms of collective resistance emphasize this view (Awad 1984; Sharp and Safieh 1987; Bakan and Abu-Laban 2009; Chenoweth and Stephan 2011; Qumsiyeh 2011; Darweish and Rigby 2015; see Pearlman 2011 for a comparison of violent and nonviolent resistance). In contrast to their large-scale mobilization during the intifadas, Palestinians have however refrained from similar mass uprisings over the last decade. Even during the Arab Spring, when neighboring countries were swept by revolutionary protests, the Occupied Territories were among the quietest settings (Yom and Gause 2012). This was the case although an extensive protest infrastructure was available, which is known to support mobilization in other contexts (cf. McAdam, Tarrow, and Tilly 2001; Chenoweth and Ulfelder 2017).

The following analysis shows that Palestinians consider collective resistance to be highly costly and to carry low chances of success. Non-collective resistance offers an alternative channel, which nevertheless remains largely unexplored (exceptions are Richter-Devroe 2018; Rick 2006; Siegman 2020).

\section{Methodology}

This study has implications beyond the location of its field research. The unit of analysis is the individual under oppression, the main actor in non-collective resistance. The study focuses on a particular oppressive environment to ensure the establishment of analytically comparable units (Gerring 2004). The main data collection method is ethnographic interviews (Spradley 1979), which are subsequently coded to identify common trends of noncollective resistance. On the basis of this coding, new forms of nonviolent, non-collective resistance are identified-beyond exit, voice, and loyalty. While the context of this study is idiosyncratic and the sample of respondents nonrandom, the newly identified types of resistance can inspire new hypotheses for further research in other contexts of oppression, allowing for generalization.

A highly risky setting for collective resistance, the Occupied Palestinian Territories could be considered a "least-likely" environment to study resistance (Levy 2008). Nevertheless, oppressive settings still leave opportunity structures for non-collective behavior as a channel of resistance. The literature suggests that resistance follows political opportunities (McAdam, Tarrow, and Tilly 2001, 14-18; Chenoweth and Ulfelder 2017). The Occupied Palestinian Territories represent such a setting.

Fieldwork for this study was conducted from June to August 2017. More than one hundred Palestinians were approached for interviews, and thirty-two agreed to participate. ${ }^{7}$ This is a common sample size for ethnographic studies and an above-average response rate given the sensitive nature of this research. ${ }^{8}$ The participants constitute a diverse group of Palestinians. They come from three cities in the West Bank, namely Bethlehem (20), Ramallah (5), and Hebron (2), as well as East Jerusalem (5). They include fourteen women and eighteen men in their twenties (14), thirties (7), fourties (4), fifties (3), sixties (2), and seventies (2). Fifteen interviewees worked as employees in hotels, copy shops, tourist shops, wood factories, banks, at universities, and the UN. Three interviewees were doctoral students, one was a post-doctoral researcher, one was a university professor, and two were teachers. Four were directors of NGOs and a cultural institute, three owned shops and a hotel, one was a manager in a hair salon, one was a start-up founder, and one was a priest.

The interview analysis applied coding procedures based on grounded theory (Strauss and Corbin 1990). Accordingly, each interview was examined line by line in an iterative process. In the first stage, interviews were coded for experiences of oppression. In later stages, segments of text that contained descriptions of oppression were coded 
for responses to the oppression. ${ }^{9}$ These responses were classified as non-collective resistance effort based on the individuals' own vocabulary (examples follow). Subclassifications of signaling, persevering, eschewing and coping were adopted by linking the subjects' description of their actions to the literature. A majority of interviews contained descriptions of several non-collective resistance efforts. ${ }^{10}$ In total, thirteen individuals described signaling, twenty-five elaborated on persevering, twenty-three discussed eschewing, and sixteen described coping.

\section{Signaling}

Signaling is a concept applied widely in international relations, including studies on cooperation, crises, and war (Lohmann 1993; Fearon 1994; Wolford 2014; McManus 2018). In these contexts, signals are either formal and highly visible, such as the formation of an alliance (Hollyer and Rosendorff 2011), or informal and less visible, such as military aid (McManus and Yarhi-Milo 2017).

This article connects signaling to oppressed individuals at the intra-state level. In this context, signaling is a speech act conveying information about the oppressed. As opposed to Hirschman's "voice," signaling excludes direct communication with the regime and does not aim at voicing dissent. Rather, its targets are members of the in-group (the oppressed community) as well as outsiders not involved in the oppression, and its aim is to spread knowledge about the perpetrators and the victims that contrasts the regime's narrative perpetuating the oppression. This knowledge may subsequently support feelings of sympathy (cf. Ewick and Silbey 1995), compassion (Schulte-Rüther et al. 2007; Saarela et al. 2007), and solidarity (Koudenburg, Postmes, and Gordijn 2013; Droogendyk et al. 2016, 318) among the recipients of the signal. Some of these emotions have the potential of being translated into collective action or increased noncollective resistance.

Studies on collective resistance have often highlighted the importance of solidarity (e.g., Stewart et al. 2016; Wilson and Brown 2008). ${ }^{11}$ On the one hand, solidarity has been found to motivate out-group members to act on behalf of disadvantaged or oppressed groups (Droogendyk et al. 2016; Dornschneider 2019a). Such actions have been connected to large-scale movements that have made a lasting impact, such as economic damage (e.g., the Boycott, Divestment and Sanctions movement; see Bakan and Abu-Laban 2009), constitutional change, or governmental resignation (e.g., in the Arab Spring, see Dornschneider 2019a). On the other hand, solidarity has been found to strengthen the commitment to action among members of the same group (Reicher et al. 2006, 52). In oppressive environments characterized by high levels of insecurity, in-group solidarity is known to be especially high (Inglehart, Moaddel, and Tessler 2006; cf. Gourlay
2018), even when levels of collective action are low. Signaling provides a mechanism for solidarity to emerge or spread in these environments.

At the in-group level, signaling can also bolster the political identity of the oppressed, which is a crucial ingredient of political resistance (van Zomeren, Postmes, and Spears 2008). Communication between in-group members can create an awareness of shared grievances and adversarial attributions, which can generate selfconsciousness where individuals see themselves as part of a struggle on behalf of their group (Simon and Klandermans 2001).

Finally, signaling may be "health-inducing" for the individual victims of oppression by enabling them to feel stronger and abler to respond to their grievances (Wade 1997). By extension, the group of victims as a whole can be strengthened, if a sufficient number of its members engage in signaling.

\section{Descriptions of Signaling}

The interview analysis identified signaling in conversations, daily interactions, the arts, work, writing, and translating. ${ }^{12}$ Typically, these efforts were described as the preferred alternative to collective forms of resistance. The signals' contents addressed the Israeli oppression, related personal grievances, as well as Palestinian identity and interests.

\section{Out-Group Signaling}

The director of an NGO started the interview by communicating a personal grievance. Presenting a map dating back to the time of the Ottomans, he asked: "Do you see this land? This is our land, and this is the wall. So all the land is behind the wall." He said his family had used the land to plant barley, but Israel annexed it when building the wall sealing off the West Bank. The land was now divided by a road, and there were plans of building a settlement on it. "For the Israelis, I don't exist. I am an absentee, I have no access." He said reclaiming his land in court was not an option due to Israeli jurisdiction: "They will say: 'This land is annexed. It is part of Jerusalem. You have no right to be there.' If you go to court and lose the case, you lose your right to appeal later. It's a political issue. You lose your land as well." Instead, he started talking to outsiders, including journalists, diplomats, or academics, and engaged in resistance by making them aware of the loss of his land: "Every time I am invited to speak about settlement, I bring this issue."

Other interviewees said they engaged in signaling by informing foreigners about the occupation:

I do not participate in direct confrontation with the occupier because I do not live in a refugee camp or in Gaza. I use other ways to resist the occupation, writing and research. I believe in the importance of research on what is happening in Palestine, 
especially in English, so that we can show the world the Palestinian voice. I concentrate my efforts on writing political articles and op-eds in English, so that the people in America, in the UK, and in Germany see what is happening from the Palestinian point of view.

\section{Referring to the impact of her effort, she said:}

Israel dominates the media and has a huge propaganda machinery. My work makes my life more meaningful in the sense that I feel I am actively doing something that is meaningful to me and that challenges the occupation in the long run.

Another interviewee sent signals to foreigners by translating Arabic news into English: "I love my people. I love helping them. So if I get a press release in Arabic, I have no problem translating that. But I do not want to be directly engaged [in politics], as the authorities do not care about the people."

Interviewees working in the tourism industry said they sent signals through interacting with their clients. Their signals often contained information challenging negative views of Palestinians. The owner of a hotel in Bethlehem said: "This is my work. My job is to show the world who the Palestinian people are and how they live here in this hotel. I do this job to give a positive image of the Palestinians."

An employee who sold souvenirs in a shop downtown explained:

The problem is that we work in tourism as you can see. The people who visit think Bethlehem is Israel! Even Arabs talk to us in Hebrew and tell us we are terrorists: "You are Palestinians, so you are of course trained to fight." That is a different image. The news paint an image of us as if we were the devil.

He said he confronted this image in daily interactions with his customers, exclaiming: "We are welcoming the people!"

\section{In-Group Signaling}

At the in-group level, signals were given in daily interactions with community members, including family, friends, colleagues, and strangers. A mother from Bethlehem said she communicated information about Palestinian interests to her children:

I prefer staying far away from politics. I choose another way. I love my land, and I raise my children so that they love their land. I support them and teach them how to support their land without getting involved in politics ... This is my means. They will serve their country and protect it. You do not have to become a politician to serve your country.

A start-up founder reminded other Palestinians of their identity, and questioned compliance with Israeli interests:

We need an education of the Palestinian people of their own history, but I only engage in it in a non-systematic fashion. If I walk into a shop and they are selling three different options of Israeli dairy, I ask the owner: "Why on earth are you selling Israeli dairy? Why are you facilitating [them]?" It's minimal interactions like that, not active participation in a program.
Other interviewees sent signals through the arts that spoke to identity issues. The director of a cultural center in Jerusalem said: "In politics, you take a long time and contribute no solution." At the time of the interview, she was preparing a new exhibition space. She said: "You have to work on expanding Palestinian culture and education. You need to teach them how to think. This is much more important for the Palestinian people than all of the international aid combined." A priest who created art projects said:

There are many forms of resistance. The arts are also a kind of resistance -images, painting, movies, dancing and drama ... The arts cannot overcome the occupation, but they can provide the Palestinians with a new means to express themselves.

An employee in a copy shop had written a political movie. "To live peacefully, I talk about the Israelis," he said. "I am only one person, I concentrate on my culture and on my nationality, but in a peaceful way to avoid confrontation." His movie conveys the message that Palestinians have to confront their suffering through respectful negotiation:

There is no respect anywhere. Not every Israeli is bad, there are good and bad people. But the nature of the relation between us is that there is occupation. If someone comes and occupies your house with five friends, I don't feel respect, I feel put against the wall. How should I try to get from here to there? With respect. If I shout "I want to go there!", they will put me in a corner.

\section{Persevering}

Perseverance is a well-known concept in psychology referring to a sustained effort to overcome challenges in spite of failures and setbacks (Rothermund 2003; Duckworth et al. 2007; Williams and DeSteno 2008; Datu, Valdez, and King 2016). Perseverance is considered crucial to the achievements of individuals, such as long-term goals like completing an education, performing well at work, or reaching a certain career level (Markman, Baron, and Balkin 2005; Duckworth et al. 2007; Lamont, Kennelly, and Moyle 2014), as well as short-term goals, such as completing a repetitive task (White et al. 2017).

The following analysis connects perseverance to resistance rather than achievement. In this context, the challenge that needs to be overcome is an oppressive regime. Facing this challenge is risky, and failure and setbacks can mean death or imprisonment. Consequently, perseverance under oppression is related to activities that are carefully selected, and less visible than activities typically associated with achievement. Seemingly mundane and unimportant behaviors, such as living in a certain place or going to work, may constitute examples of persevering by which individuals obstruct regime efforts of exercising control over them. In the Palestinian context, where Israel is trying to expel the oppressed community through settler colonialism, individuals contrast perseverance with emigration, 
which is considered a means of giving in. This understanding departs from existing accounts of "exit," which treat emigration as a form of resistance.

A few studies on resistance have applied the concept of perseverance to address the survival of endangered communities that face severe disadvantages and existential threats, such as poor black women living in slums (Hossein 2013) or clerics under the Nazi regime (Jantzen 2001). Rather than addressing perseverance in particular activities that are conducted by individuals, these studies understand perseverance as a collective achievement. In the context of Palestinian resistance, perseverance can also be conceptualized as resilience, which is achieved through the collective creation of family and community networks, stimulated by shared trauma (Atallah 2017).

In the Palestinian context, perseverance has also been addressed by the concept of "sumūd," which translates into "steadfastness" (Johansson and Vinthagen 2015; also see Farsakh 2016, 59). Introduced by the PLO as a political term, sumūd has been applied referring to the Palestinians' strength to survive and resist in a hostile environment (Farsakh 2016). Subsequent research has struggled to conceptualize sumüd, referring to it via attitudes, traits, mental stance, and activities as widely as education, laughing, or developing inner peace (Johansson and Vinthagen 2015). The concept of perseverance presented in the following analysis shows similarities to Richter-Devroe's (2011) study of Palestinian women in Israeli prisons, which perceives of sumūd as a daily struggle to maintain a normal life in spite of the occupation. ${ }^{13}$

\section{Descriptions of Persevering}

The interview analysis identified persevering related to living in Palestine, maintaining daily life, and protecting private space. ${ }^{14}$ Numerous interviewees said they persevered by refusing to emigrate and staying in their hometowns in spite of Israeli efforts to expel them. In the words of a shopkeeper from Jerusalem: "The goal of the Israelis is to push us out of Jerusalem. All of this pressure that they are making has the goal of driving us out. And in spite of all of this pressure that they are producing, the resistance becomes visible by us staying."

Some interviewees persevered in their livelihoods even after Israel took their land. A souvenir vendor said: "We have land, but they built the wall, and our land was gone. Imagine! We are talking about 10 dunum [unit of area equivalent to English acre] of land." The family nevertheless decided against emigration: "The idea is to support our land by living here."

Others persevered in their lives in spite of violence threatening their family: "We are living with the Israeli army. Maybe there is a martyr in your life or in your district. Maybe they killed your uncle or your brother. Or maybe there is a bomb. This situation is normal for us. We still go out and live our lives."

Various interviewees described persevering in spite of economic hardship. One interviewee said: "I am constantly trying to develop, but not much is happening because life is very difficult .... I work five days a week, I do every job I can get to make ends meet."

Other interviewees described persevering in spite of challenges at work. A university employee said he continued organizing international events although invitees were frequently denied entry to the West Bank:

Yesterday we had a workshop and we met people from Kenya, we met people from Italy. All of that is engaging. All of that is considered a normal life. Of course, there were difficulties. For example, we were also expecting people from Nepal. They were not given visas. Israel did not issue visas. So we face these issues. But these issues will not stop us from moving and from going on.

A minority of interviewees ${ }^{15}$ described persevering by protecting private space. One individual recalled an incident at her house:

The army came into our house and my siblings started to cry. I got very angry. So I went to the soldiers and told them: "Get out! This is private property, this is my house." One of the soldiers told me: "Go inside, or I will kill you." I got very angry and told him: "Kill me! You are a soldier and I am a very small person." My siblings were very afraid and hid under the table. But I did not want to give him the power and disappear. So I stayed. He continued to say: "Go inside or I will shoot and kill you." I kept repeating: "I will not move." So he shot me, but the bullet only graced my face.

Many interviewees yearned to escape their environment but chose to persevere instead. "There is no doubt that I want to leave and work abroad, but there is a feeling deep inside my body that this is my homeland," one interviewee said. Others turned down opportunities to emigrate: "I am not obliged to live here, I live here to support my land. I would have better opportunities if I emigrated and lived abroad, but I reject that primarily because my land is here." Some had lived abroad but returned: "I studied abroad. I always wanted to return. It is very important that every individual serves the Palestinian community in their own way."

Persevering was often described as an effort that was necessary to resist expulsion and ensure the continuation of Palestinian life. In the words of a student:

If we don't go to school, we won't learn anything. If we don't work, we won't have money to live. If we don't get married, we won't have children and will vanish from this place. So we get married and have children. This is a natural behavior. We have to live.

Another interviewee said: "If I leave, my brothers and sisters will leave, and the neighbors. And then the land will go to the occupier. That is what lets us endure here and live under these difficult conditions." 


\section{Eschewing}

Eschewing is a well-known concept in politics and economics (Weaver 1986; Brett et al. 1998; Parnell 2010; Gnedina and Sleptsova 2012; Dam and Scholtens 2015). It is typically understood as a strategy applied to avoid losses, adopted in deliberations about the costs and benefits of certain behavior. This includes collective forms of nonviolent resistance, where violent means may be avoided based on ethical principles and low chances of success (Chenowetz and Stephan 2011), and collective forms of violence where hard targets may be avoided because they are especially difficult to destroy (Enders and Sandler 2011).

Non-collective resistance often eschews high visibility, which decreases the potential for governmental retaliation (Scott 1987). Specifically, the following analysis shows that individuals avoid direct confrontation with the regime as well as mundane interactions that make them visible to Israeli authorities. Interviewees consider this avoidance a resistance effort because it enables them to persevere in their daily lives. ${ }^{16}$ In the words of an interviewee from Jerusalem:

There is no possibility to resist the Israelis because of their incredible strength and toughness. So if the police give me a fine for no reason, there is no way to reject it and I accept this punishment. That is a kind of resistance here in Jerusalem. It is a peaceful resistance. People are trying to live their daily lives. You must live your daily life.

\section{Descriptions of Eschewing}

The interview analysis identified numerous eschewing efforts related to direct confrontation (both collective and non-collective) and interactions with Israelis. ${ }^{17}$ The abovementioned interviewee from Jerusalem said avoiding direct confrontation with Israeli authorities was part of his daily life. He said: "In every minute of your life, there are a lot of experiences of the occupation." His most frequent experience was the payment of fines and public services that were never delivered, to which he referred as "the occupation tax." He said: "In America they say "no taxation, no representation.' Here, the taxes are like the Egyptian baltagiya [thugs hired to attack regime targets]. You just pay them to avoid someone attack you, you just pay for the gangster to avoid trouble." By avoiding direct confrontation in this way, he said, Palestinians could contain Israeli punishment and stay out of prison:

The most important part of living here is to stay calm. The people here must stay calm. Emotions are not a good thing because the frictions with the Israelis will get very rough and end in prison. So you do nothing. You must stay cool.

Another interviewee, who lived behind the wall, said his most frequent experience of the occupation was being prevented from traveling to Jerusalem and abroad.
Avoiding confrontation was key to dealing with these experiences: "What can I do? To whom can I complain? At the end of the day, they are the occupier and they are the ones who set the rules." He said challenging the denial of travel visas would only worsen his situation: "It would not help me. Probably it becomes a black point in my record." Instead, he focused his efforts on "moving on:"

I have to accept the reality. I have to accept it [being denied a travel permit] could happen any moment, so that it does not upset me when it happens. It bothers me probably for a short while and then life goes on. This is the reality of life.... Either I get frustrated and stop moving because of this incident, or I consider this as one incident in life. That's usually what I do, I accept and move on. I think that most Palestinians are doing the same.

Other interviewees said they avoided interacting with Israelis. An interviewee living in the $\mathrm{C}$ area in the West Bank said she saw Israeli soldiers every day but never spoke with them. She said: "I try to avoid that and to stay away from them."

Others avoided confronting Israelis through protest. "That will never work in this reality," an interviewee said. "They believe we are terrorists, even though we are peaceful. They are attacking us without a reason. I believe being peaceful is better. We do not like dead or wounded people." Another interviewee, who had been imprisoned, said:

There is no solution. If you open your mouth, the army will come and get you. They enter your house and put you in prison. They will enter your house and take away your family. If I do anything against them, they will come and kill my sister.

A Palestinian who boycotted Israeli goods said:

I do not believe in throwing stones at the wall because this kind of resistance does not bring any result. If we want there to be a result, we can engage in peaceful resistance. This does not involve martyrs and nobody dies, and we protect our youths.

\section{Coping}

Coping is a response to threat or harm and its resulting distress (Carver and Connor-Smith 2010). It can address both chronic stressors that continue over a long period of time and acute stressors that pose extreme threats at certain moments (Day and Livingstone 2001). Coping can be an active and deliberate behavior, employed with the goal of preventing or minimizing distress and its associated threat (Carver and Connor-Smith 2010; Lazarus and Folkman 1984).

The following analysis shows that individuals apply coping to resist the distress inflicted on them by the oppression. Their coping efforts consist of self-soothing activities, such as travelling or exercising, which reduce their distress and enable them to stay calm in the face of both chronic (e.g., checkpoints) and acute (e.g., armed attacks) stressors. This behavior and its associated benefits 
obstruct oppressive regimes by limiting the effect of the oppression and, by extension, regime control over individuals.

Self-soothing activities are a kind of emotion-focused coping, which is less risky than other forms of coping because it targets the distress imposed by a stressor, rather than the stressor itself (Carver and Connor-Smith 2010). Emotion-focused coping is known for its capacity of reducing negative distress and making careful deliberation about a problem possible (Lazarus, 2006).

Self-soothing activities also constitute a form of engagement coping, which is contrasted with disengagement coping that creates a distance to the stressor, such as denial or wishful thinking (Skinner et al. 2003). Engagement coping is considered more effective to cope with stress in the long-term because it acknowledges the stressor rather than denying its existence. It can offer individuals a sense of control and help them accommodate and find meaning in stressful situations (Carver and Connor-Smith 2010).

Engagement coping is not usually connected to individuals under oppression, who experience extreme exposure to stressors. Typically, individuals in stressful environments are considered to suffer from mental illnesses (Day and Livingstone 2001; Qouta, Punamäki, and El Sarr 2003), which severely impact mental health and weaken their ability to resist. They are also believed to resort to violence, especially in the Palestinian context (Hirsch-Hoefler et al. 2016; Jaeger and Paserman, 2006; Ricks 2006; Barber 2001). In contrast, the following analysis shows that, rather than passively suffering or violently resisting their stressful environment, individuals under oppression take concrete steps to stay calm.

\section{Descriptions of Coping}

Interviewees described coping related to the arts, travel, sports, family, study, and work. ${ }^{18}$ Acknowledging stressors instead of denying their existence, these efforts reduced their distress and helped them stay calm or find meaning in stressful situations. Some stressors described by individuals were Israeli violence, checkpoints, or continuous thinking about the occupation.

"There are many unnatural limitations," one interviewee said. "The most important one is the restriction of thought. What they allow you to think." To cope with the resulting distress, interviewees engaged in the arts, which helped them feel empowered and hopeful. "Some of us are dying on the inside. The arts can provide the self with a new source of power, to express yourself and to express the hope of the Palestinians in a creative way," one interviewee said.

Others coped through traveling, which helped them reduce their distress and gain strength. An interviewee from Jerusalem said: "I travel. Traveling helps me relax. I am not relaxed normally because of the occupation. Maybe someone dies or is stabbed. I work in the Old City, where there are a lot of tensions. Maybe a little child dies." Another interviewee said: "At the end of the day I am just feeling tired. Exhausted from this lifestyle. The hope is gone. We need hope." Traveling gave her strength: "I went to Jordan last year. Traveling renews your life."

Others reduced their distress through sports. An interviewee from Ramallah said: "I go to the gym five times a week. Sports is the best means for me to get rid of stress. If I stand on the treadmill for 30 minutes, I get rid of everything." She said she needed "to feel comfortable" to confront the negative emotions she experienced at work, for which she often visited Gaza:

All my emotions are at the border [to Gaza]. I hate everything. I don't like anything. Not because of myself but because of the victimization at the border. I have to see old women and disabled people being treated very badly. This type of wickedness influences your thoughts tremendously and I arrive at work and do not want to work.

Another interviewee said: "I do yoga to reduce my stress." She said: "The main experience in my daily life is restricted movement. Movement is very difficult, and your brain is always preoccupied with it. Maybe I want to walk to the Damascus gate, but I am surprised to find a lot of problems on my way that force me to turn around. You can never do what you planned."

Another interviewee coped by spending time with his family. He mentioned an incident the night before the interview, when the Israeli army entered the house of his neighbour, and Palestinian boys threw stones that smashed a window and damaged his car. He commented:

Maybe I have thoughts about the occupation, but I cannot talk about them. Maybe I can control myself, but maybe others experience such strong pressure on the inside that they explode. I am a very normal person, and I have a consciousness. That's why I spare myself from these experiences. If I have a bad idea, I turn to something else, and that is my family. Whenever there is pressure, I go to my family.

Other interviewees said their work constituted an important coping effort. "I am working in development," one interviewee said. "When I go to a Bedouin in the heart of the desert and, for the first time, they have light and can watch TV, this is a very rewarding experience for me. I sleep very well that night." Another interviewee volunteered in the field of mental health. She said: "We have to work on our mentalities. We have become used to being the victims, and we like this role, although it is destroying us." She believed: "We have mental issues and have to work on ourselves to confront the Israeli power, because they are very smart and use everything against us. We may fight against the occupation when we adopt a healthy lifestyle." 


\section{Conclusion}

Previous work in political science often assumed that individuals in highly oppressive settings quietly tolerate or fearfully endure their rulers. Some research has considered violence as a major resistance effort in these settings. By contrast, I have identified peaceful forms of non-collective resistance by which individuals deliberately obstruct oppressive rulers. Based on research in the highly oppressive context of the Occupied Palestinian Territories, I show that even in this environment, individuals resist rather than passively endure their suffering.

The analysis has shown that individuals resist their rulers through signaling, persevering, eschewing, and coping. These non-collective efforts were identified from interview transcripts containing detailed descriptions of individual responses to their experiences of the oppression. Responses were classified as resistance efforts based on the interviewees' own vocabulary, and subsequently grouped into separate categories by referring to well-known concepts from the literature of psychology and international relations. The resulting classification complements existing accounts of transgressive practices of individuals under oppression.

Interviewees reported feeling empowered by their resistance efforts, both regarding their community and their personal conditions. Through signaling, they communicate information challenging the regime narrative, which can strengthen their community and lead to collective action on their behalf. Through persevering in mundane activities and eschewing activities that put them at risk, they ensure the continuation of their daily lives and obstruct regime efforts to expel them. Through coping, they limit the effect of the oppression on their mental health and resist regime control.

While echoing theories in social science and especially in psychology, these strategies of resistance have only rarely been connected to resistance under oppressive regimes. Taken together, they appear to have a genuine impact, but in-depth future research into each is necessary to fully assess their effectiveness. Some interviewees were optimistic that their efforts would succeed. "When the wall [barrier to Israel] comes down, we will return home," one interviewee said. "Look at what happened to the Berlin wall.”

\section{Acknowledgement}

Dornschneider is very grateful to her interviewees and to those who helped her set up interviews, especially Gigi and Riccardo Bocco. She received many valuable comments that have greatly improved this article. She is particularly grateful to the four anonymous reviewers. She also wishes to thank her colleagues at University College Dublin, Kirssa Cline Ryckman and the participants of the panel
"Social Movements, Protests, and Resistance" at the 2018 annual meeting of the International Studies Association, as well as Tereza Capelos, Jolanda van der Noll and the participants of the panel "The Psychology of Grievances and Political Activism," convened by the Political Psychology Standing Group during the 2019 annual meeting of the European Consortium for Political Research. She is grateful for financial support from the College of Social Sciences and Law (grant number SF1598) and the School of Politics and International Relations at University College Dublin.

\section{Notes}

1 Note that it may be performed independently by large numbers of people; cf. Scott 1985.

2 Environments characterized by vertical oppression may be more difficult to access. Studies of noncollective resistance have often focused on disadvantaged groups, such as peasants, women, or the poor (e.g., Scott 1987; Gillespie 2017; Asgari and Sarikakis 2019) in comparatively more open or transforming societies. Critical theorists have emphasized the importance of the intersectionality of these identities and their related resistance efforts, e.g., Vinthagen and Johansson 2013.

3 Also see Wedeen's terminology of "hidden in plain sight" $(2019,24)$. Note, however, that she applies the concept to "neoliberal lifeways" and power maintenance by the Syrian regime, rather than resistance.

4 Note that research has recognized additional types of hidden resistance, namely direct resistance by hidden resisters, hidden transcripts or discourse, and subcultures, which target material, status, and cultural domination, respectively; Vinthagen and Johannsson 2013.

5 See, for example, Goldstone 1991; Bermeo 2003; Wood 2003; Schock 2005; and Nepstad 2011.

6 The Occupied Territories have among the highest ratios of security personnel to civilians in the world. In addition to the Israeli military, there are 83,000 Palestinian security personnel at present in Gaza and the Occupied Territories combined; European Council on Foreign Relations 2020.

7 Refer to the online appendix for interview recruitment and conduct, as well as an anonymized list of the interviewees.

8 By comparison, a study of 560 doctoral theses showed that the mean sample size for qualitative interviews was thirty-one; Mason 2010. Other studies of populations that are difficult to access include similar sample sizes; Linden and Klandermans 2007; Dornschneider and Henderson 2016. According to Becker, even a single interview can be "quite sufficient" to show that something is possible (in Baker and Edwards 2012). 
9 For a detailed description of the coding of the interview transcripts of this study see Dornschneider 2019b.

10 Four individuals engaged in one type of non-collective resistance, fifteen engaged in two types of resistance, nine in three types of resistance, and four in four types of resistance.

11 This includes the context of Palestine, e.g., Sharoni 1995, 2.

12 Six individuals referred to conversations, two to daily interactions, two to work, two to writing, two to the arts, and one to translation. Participation in this study could be considered a type of signaling to the outgroup, although only one interviewee made this explicit.

13 In Richter-Devroe 2011, sumūd includes a broader range, including material (income generation), cultural (singing and dancing), and social and ideational (keeping up hope) activities.

14 Eight individuals referred to staying in Palestine, five to their return to Palestine, ten to the maintenance of daily life (six to work and four to raising children), and two to securing a particular location.

15 Two of thirty-two individuals. This type of persevering is exceptional because it includes direct interactions with Israelis, which was typically avoided.

16 As such, eschewing is the absence of behavior, typically employed in combination with persevering, and, in this combination, understood as a form of obstruction of the oppressive regime.

17 Fifteen individuals commented on avoiding collective resistance, four on non-collective confrontation, and four on direct interactions.

18 Four described traveling, three mentioned the arts, two referred to sports, and one family life. Five described coping through studying and four through working. Regarding travel, note that this study focuses on Palestinians in the West Bank who can apply for travel visas. Nevertheless, as described in the previous sections, they are often denied such visas and risk being denied re-entry on their return. Travelling is not an option available to Palestinians in Gaza.

\section{Supplemental Materials}

Interview Recruitment

Interview Conduct

Interview Analysis

List of Interviewees

To view supplementary material for this article, please visit http://doi.org/10.1017/\$1537592720004818.

\section{References}

Abu-Amr, Ziad. 1993. "Hamas: A Historical and Political Background." Journal of Palestine Studies 22(4): 5-19.
Abu-Lughod, Lila. 1990. "The Romance of Resistance: Tracing Transformations of Power through Bedouin Women.” American Ethnologist 17(1): 41-55.

Alawattage, Chandana, and Danture Wickramasinghe. 2009. "Weapons of the Weak: Subalterns'

Emancipatory Accounting in Ceylon Tea." Accounting, Auditing \& Accountability Journal 22(3): 379-404.

Arab Barometer V. 2019 "Palestine Country Report."

Retrieved April 1, 2020 (https://

www.arabbarometer.org/wp-content/uploads/ palestine-report-public-opinion-2019.pdf).

Asgari, Helia, and Katharine Sarikakis. 2019. "Beyond the 'Online:' Iranian Women's Non-Movement of Resistance." Journal of Arab \& Muslim Media Research 12(2): 235-252.

Atallah, Devin G. 2017. “A Community-Based Qualitative Study of Intergenerational Resilience with Palestinian Refugee Families Facing Structural Violence and Historical Trauma." Transcultural Psychiatry 54(3): 357-83.

Awad, Mubarak E. 1984. "Non-Violent Resistance: A Strategy for the Occupied Territories." Journal of Palestine Studies 13(4): 22-36.

Baconi, Tareq. 2018. Hamas Contained: The Rise and Pacification of Palestinian Resistance. Stanford, CA: Stanford University Press.

Bakan, Abigail B., and Yasmeen Abu-Laban. 2009. "Palestinian Resistance and International Solidarity: The BDS Campaign.” Race \& Class 51(1): 29-54.

Baker, Sarah Elsie, and Rosalind Edwards, eds. 2012. "How Many Qualitative Interviews Is Enough." National Centre for Research Methods Review Paper. Retrieved March 15, 2020 (http://eprints.ncrm.ac.uk/2273/4/ how_many_interviews.pdf).

Barber, Brian K. 2001. "Political Violence, Social Integration, and Youth Functioning: Palestinian Youth from the Intifada." Journal of Community Psychology 29(3): 259-80.

Bayat, Asef. 2000. "From 'Dangerous Classes' to 'Quiet Rebels': Politics of the Urban Subaltern in the Global South." International Sociology 15(3): 533-57. https:// doi.org/10.1177\%2F026858000015003005

BBC. 2020. "Israeli-Palestinian Violence Flares Up." Retrieved April 1, 2020 (https://www.bbc.com/news/ world-middle-east-51397355).

Berkowitz, Leonard. 1989. "Frustration-Aggression Hypothesis: Examination and Reformulation." Psychological Bulletin 106(1): 59-73.

Bermeo, Nancy G. 2003. Ordinary People in Extraordinary Times: The Citizenry and the Breakdown of Democracy. Princeton, NJ: Princeton University Press.

Bloom, Mia M. 2004. "Palestinian Suicide Bombing: Public Support, Market Share, and Outbidding." Political Science Quarterly 119(1): 61-88. 
Brett, Jeanne M., Wendi Adair, Alain Lempereur, Tetsushi Okumura, Peter Shikhirev, Catherine Tinsley, and Anne Lytle. 1998. "Culture and Joint Gains in Negotiation.” Negotiation Journal 14(1): 61-86.

Btselem. 2019. "Statistics on Settlements and Settler Population.” Retrieved April 1, 2020 (https:// www.btselem.org/settlements/statistics).

Bueno De Mesquita, Bruce, James D. Morrow, Randolph M. Siverson, and Alastair Smith. 1999. "Policy Failure and Political Survival: The Contribution of Political Institutions." Journal of Conflict Resolution 43(2): 147-61.

Carver, Charles S., and Jennifer Connor-Smith. 2010. "Personality and Coping." Annual Review of Psychology 61:679-704.

Chenoweth, Erica, and Maria J. Stephan. 2011. Why Civil Resistance Works: The Strategic Logic of Nonviolent Conflict. New York: Columbia University Press.

Chenoweth, Erica, and Jay Ulfelder. 2017. "Can Structural Conditions Explain the Onset of Nonviolent Uprisings?" Journal of Conflict Resolution 61(2): 298-324.

Colomer, Josep M. 2000. "Exit, Voice, and Hostility in Cuba." International Migration Review 34(2): 423-42.

Dam, Lammertjan, and Bert Scholtens. 2015. "Toward a Theory of Responsible Investing: On the Economic Foundations of Corporate Social Responsibility." Resource and Energy Economics 41:103-21.

Darweish, Marwan, and Andrew Rigby. 2015. Popular Protest in Palestine. The Uncertain Future of Unarmed Resistance. London: Pluto Press.

Datu, Jesus Alfonso D., Jana Patricia M. Valdez, and Ronnel B. King. 2016. "Perseverance Counts but Consistency Does Not! Validating the Short Grit Scale in a Collectivist Setting." Current Psychology 5(1): 121-30.

Day, Arla L., and Holly A. Livingstone. 2001. "Chronic and Acute Stressors among Military Personnel: Do Coping Styles Buffer Their Negative Impact on Health?" Journal of Occupational Health Psychology 6(4): 348-60.

Dollard, John, Neal E. Miller, Leonard W. Doob, Orval Hobart Mowrer, and Robert R. Sears. 1939. Frustration and Aggression. New Haven, CT: Yale University Press.

Dornschneider, Stephanie. 2019a. "High-Stakes Decision-Making within Complex Social Environments: A Computational Model of Belief Systems in the Arab Spring." Cognitive Science 43(7): e12762.

_. 2019b "Analyzing Ethnographic Interviews: Three Studies on Terrorism and Nonviolent Resistance." International Political Science Review. https://doi.org/10.1177/0192512119884091.
Dornschneider, Stephanie, and Nick Henderson. 2016. "A Computational Model of Cognitive Maps: Analyzing Violent and Nonviolent Activity in Egypt and Germany." Journal of Conflict Resolution 60(2): 368-99.

Dowding, Keith, Peter John, Thanos Mergoupis, and Mark Van Vugt. 2000. "Exit, Voice and Loyalty: Analytic and Empirical Developments." European Journal of Political Research 37(4): 469-95.

Droogendyk, Lisa, Stephen C. Wright, Micah Lubensky, and Winnifred R. Louis. 2016. "Acting in Solidarity: Cross-Group Contact Between Disadvantaged Group Members and Advantaged Group Allies." Journal of Social Issues 72(2): 315-34.

Duckworth, Angela L., Christopher Peterson, Michael D. Matthews, and Dennis R. Kelly. 2007. "Grit: Perseverance and Passion for Long-Term Goals." Journal of Personality and Social Psychology 92(6): 1087-101.

Economist. 2018. "How to End the Endless Conflict between Israel and the Palestinians." Retrieved April 1, 2020 (https://www.economist.com/ leaders/2018/05/17/how-to-end-the-endless-conflictbetween-israel-and-the-palestinians).

El Zein, Rayya. 2017. "Developing a Palestinian Resistance Economy through Agricultural Labor." Journal of Palestine Studies 46(3): 7-26.

Enders, Walter, and Todd Sandler. 2011. The Political Economy of Terrorism. Cambridge: Cambridge University Press.

European Council on Foreign Relations. 2020. "Mapping Palestinian Politics." Retrieved 28, August 2020. (https://www.ecfr.eu/mapping_palestinian_politics/ detail/introduction_security_forces).

Ewick, Patricia, and Susan S. Silbey. 1995. "Subversive Stories and Hegemonic Tales: Toward a Sociology of Narrative." Law and Society Review 29(2): 197-226.

Fahy, Sandra. 2015. Marching through Suffering: Loss and Survival in North Korea. New York: Columbia University Press.

Farsakh, Leila. 2016. "Palestinian Economic Development: Paradigm Shifts since the First Intifada." Journal of Palestine Studies 45(2): 55-71.

Fearon, James D. 1994. "Signaling versus the Balance of Power and Interests: An Empirical Test of a Crisis Bargaining Model." Journal of Conflict Resolution 38(2): 236269.

Foucault, Michel. 1966. Les mots et les choses. Une archéologie des sciences humaines (The Order of Things: An Archeology of the Human Sciences). Paris: Éditions Gallimard. . 1982. "The Subject and Power." Critical Inquiry 8 (4): 777-95.

Freedom House. 2020. "Freedom in the World." Retrieved 1, April 2020 (https://freedomhouse.org/ country/west-bank/freedom-world/2020). 
Gerring, John. 2004. "What Is a Case Study and What Is It Good for?" American Political Science Review 98(2): 341-54.

Gerschewski, Johannes. 2013. "The Three Pillars of Stability: Legitimation, Repression, and Co-Optation in Autocratic Regimes." Democratization 20(1): 13-38.

Gillespie, Tom. 2017. "From Quiet to Bold Encroachment: Contesting Dispossession in Accra's Informal Sector." Urban Geography 38(7): 974-92.

Goldstone, Jack A. 1991. Revolution and Rebellion in the Early Modern World. Berkeley: University of California Press.

Gourlay, William. 2018. "Oppression, Solidarity, Resistance: The Forging of Kurdish Identity in Turkey." Ethnopolitics 17(2): 130-46.

Gnedina, Elena. and Evghenia Sleptsova. 2012. "Eschewing Choice: Ukraine's Strategy on Russia and the EU." Centre for European Policy Working Paper 360, 1-21. (https://www.ceps.eu/ceps-publications/ eschewing-choice-ukraines-strategy-russia-and-eu/).

Granovetter Mark. 1978. "Threshold Models of Collective Behavior." American Journal of Sociology 83 (6): 1420-43.

Gunning, Jeroen. 2007. Hamas in Politics: Democracy, Religion, and Violence. London: Hurst Publishers.

Gurr, Ted R. 1970. Why Men Rebel. Princeton, NJ: Princeton University Press.

Haddad, Toufic. 2016. Palestine Ltd.: Neoliberalism and Nationalism in the Occupied Territory. London: Bloomsbury Publishing.

Hellmeier, Sebastian, and Nils B. Weidmann. 2020. "Pulling the Strings? The Strategic Use of ProGovernment Mobilization in Authoritarian Regimes.” Comparative Political Studies 53(1): 71-108.

Hinnebusch, Raymond. 2012. "Syria: From 'Authoritarian Upgrading' to Revolution?" International Affairs 88(1): 95-113.

Hirsch-Hoefler, Sivan, Daphna Canetti, Carmit Rapaport, and Stevan E. Hobfoll. 2016. "Conflict Will Harden Your Heart: Exposure to Violence, Psychological Distress, and Peace Barriers in Israel and Palestine." British Journal of Political Science 46(4): 845-59.

Hirschman, Albert O. 1970. Exit, Voice, and Loyalty: Responses to Decline in Firms, Organizations, and States. Cambridge, MA: Harvard University Press.

- 1993. "Exit, Voice, and the Fate of the German

Democratic Republic: An Essay in Conceptual History." World Politics 45(2): 173-202.

Hollyer, James R., and B. Peter Rosendorff. 2011. "Why Do Authoritarian Regimes Sign the Convention Against Torture? Signaling, Domestic Politics and Non-Compliance." Available at SSRN (https:// ssrn.com/abstract=1876843) or (http://doi. org/10.2139/ssrn.1876843).
Hossein, Caroline Shenaz. 2013. "The Black Social Economy: Perseverance of Banker Ladies in the Slums." Annals of Public and Cooperative Economics 84(4): 42342.

Hroub, Khaled. 2006. “A 'New Hamas' through Its New Documents." Journal of Palestine Studies 35(4): 6-27.

Human Rights Watch. 2017. "Israel: Jerusalem Palestinians Stripped of Status.” Retrieved April 1, 2020 (https://www.hrw.org/news/2017/08/08/ israel-jerusalem-palestinians-stripped-status).

_. 2019. "Israel and Palestine." Retrieved April 1, 2020 (https://www.hrw.org/world-report/2020/ country-chapters/israel/palestine).

Inglehart, Ronald, Mansoor Moaddel, and Mark Tessler. 2006. "Xenophobia and In-Group Solidarity in Iraq: A Natural Experiment on the Impact of Insecurity." Perspectives on Politics 4(3): 495-505.

Jaeger, David A., and M. Daniele Paserman. 2006. "Israel, the Palestinian Factions, and the Cycle of Violence." American Economic Review 96(2): 45-49.

Jantzen, Kyle. 2001. “Totalitarianism: Propaganda, Perseverance, and Protest: Strategies for Clerical Survival Amid the German Church Struggle." Church History 70(2): 295-327.

Jasper, James M. 1998. "The Emotions of Protest: Affective and Reactive Emotions in and around Social Movements." Sociological Forum 13(3): 397-424.

Johansson, Anna, and Stellan Vinthagen. 2015. "Dimensions of Everyday Resistance: The Palestinian Sumūd." Journal of Political Power 8(1): 109-39.

Jost, John T., Mahzarin R. Banaji, and Brian A. Nosek. 2004. "A Decade of System Justification Theory: Accumulated Evidence of Conscious and Unconscious Bolstering of the Status Quo.” Political Psychology 25(6): 881-919.

Kalyvas, Stathis N. 2006. The Logic of Violence in Civil War. Cambridge: Cambridge University Press.

Khashan, Hilal. 2003. "Collective Palestinian Frustration and Suicide Bombings." Third World Quarterly 24(6): 1049-67.

Koudenburg, Namkje, Tom Postmes, and Ernestine H. Gordijn. 2013. "Conversational Flow Promotes Solidarity.” PloS One 8(11): e78363.

Kuran, Timur. 1991. "Now Out of Never: The Element of Surprise in the East European Revolution of 1989." World Politics 44(1): 7-48.

Lagerkvist, Johan. 2015. "The Unknown Terrain of Social Protests in China: 'Exit,' 'Voice,' 'Loyalty,' and 'Shadow.' Journal of Civil Society 11(2): 137-53.

Lamont, Matthew, Millicent Kennelly, and Brent Moyle. 2014. "Costs and Perseverance in Serious Leisure Careers." Leisure Sciences 36(2): 144-60.

Lazarus, Richard S. 2006. "Emotions and Interpersonal Relationships: Toward a Person-Centered 
Conceptualization of Emotions and Coping." Journal of Personality 74(1): 9-46.

Lazarus, Richard S., and Susan Folkman. 1984. Stress, Appraisal, and Coping. New York: Springer Publishing Company.

Lerner, Jennifer S., and Dacher Keltner. 2001. "Fear, Anger, and Risk." Journal of Personality and Social Psychology 81(1): 146-59.

Levy, Jack S. 2008. "Case Studies: Types, Designs, and Logics of Inference." Conflict Management and Peace Science 25(1): 1-18.

Lilja, Mona, Mikael Baaz, Michael Schulz, and Stellan Vinthagen. 2017. "How Resistance Encourages Resistance: Theorizing the Nexus Between Power, 'Organised Resistance' and 'Everyday Resistance."' Journal of Political Power 10(1): 40-54.

Linden, Annette, and Bert Klandermans. 2007. "Revolutionaries, Wanderers, Converts, and Compliants: Life Histories of Extreme Right Activists." Journal of Contemporary Ethnography 36(2): 184-201.

Lohmann, Susanne. 1993. "A Signaling Model of Informative and Manipulative Political Action." American Political Science Review 87(2): 319-33.

Mahmood, Saba. 2011. Politics of Piety: The Islamic Revival and the Feminist Subject. Princeton, NJ:

Princeton University Press.

Makiya, Kanan. 1998. Republic of Fear: The Politics of Modern Iraq. Berkeley: University of California Press.

Malseed, Kevin. 2009. "Networks of Noncompliance: Grassroots Resistance and Sovereignty in Militarised Burma." Journal of Peasant Studies 36(2): 365-91.

Markman, Gideon D., Robert A. Baron, and David B. Balkin. 2005. "Are Perseverance and Self-Efficacy Costless? Assessing Entrepreneurs' Regretful Thinking." Journal of Organizational Behavior 26(1): 1-19.

Mason, Mark. 2010. "Sample Size and Saturation in PhD Studies Using Qualitative Interviews.” Forum Qualitative Social Research 11(3): Article 8.

McAdam, Doug, Sidney Tarrow, and Charles Tilly. 2001. Dynamics of Contention. New York: Cambridge University Press.

McManus, Roseanne W. 2018. "Making It Personal: The Role of Leader-Specific Signals in Extended

Deterrence." Journal of Politics 80(3): 982-95.

McManus, Roseanne W., and Keren Yarhi-Milo. 2017. "The Logic of 'Offstage' Signaling: Domestic Politics, Regime Type, and Major Power-Protégé Relations." International Organization 71(4): 701-33.

Milton-Edwards, Beverley, and Stephen Farrell. 2010. Hamas: The Islamic Resistance Movement. Cambridge: Polity.

Mishal, Shaul, and Avraham Sela. 2006. The Palestinian Hamas: Vision, Violence, and Coexistence. New York: Columbia University Press.
Mitchell, Timothy. 1990. "Everyday Metaphors of Power." Theory and Society 19(5): 545-77.

Montanaro, Laura. 2019. "Discursive Exit." American Journal of Political Science 63(4): 875-87.

Morrow, James D. 1999. "The Strategic Setting of Choices: Signaling, Commitment, and Negotiation in International Politics." In Strategic Choice and International Relations, ed. David A. Lake and Robert Powell, 77-115. Princeton, NJ: Princeton University Press.

Nepstad, Sharon Erickson. 2011. Nonviolent Revolutions: Civil Resistance in the Late 20th Century. New York: Oxford University Press.

New York Times. 2020. "Violence Surges in the Wake of Trump's Mideast Plan.” Retrieved April 1, 2020 (https://www.nytimes.com/2020/02/06/world/ middleeast/israel-violence-trump-mideast-plan.html).

Palestinian Centre for Policy and Survey. 2015. "Palestinian Public Opinion Poll No-58." Retrieved April 2, 2020. (http://www.pcpsr.org/en/node/625).

Parnell, John A. 2010. "Strategic Clarity, Business Strategy and Performance." Journal of Strategy and Management 3(4): 304-24.

Peace Now. 2019. "Jerusalem Municipal Data Reveals Stark Israeli-Palestinian Discrepancy in Construction Permits in Jerusalem.” Retrieved April 1, 2020 (https:// peacenow.org.il/en/jerusalem-municipal-data-revealsstark-israeli-palestinian-discrepancy-in-constructionpermits-in-jerusalem).

Pearlman, Wendy. 2011. Violence, Nonviolence and the Palestinian National Movement. New York: Cambridge University Press.

_. 2016. "Narratives of Fear in Syria." Perspectives on Politics 14(1): 21-37.

Pew Research Centre. 2014 "Concerns about Islamic extremism on the rise in the Middle East." Retrieved April 2, 2020 (http://www.pewglobal.org/2014/07/01/ concerns-about-islamic-extremism-on-the-rise-inmiddle-east/pg-2014-07-01-islamic-extremism-08/).

Pfaff, Steven, and Hyojoung Kim. 2003. "Exit-Voice Dynamics in Collective Action: An Analysis of Emigration and Protest in the East German Revolution.” American Journal of Sociology 109(2): 401-44.

Popkin, Samuel L. (1979). The Rational Peasant: The Political Economy of Rural Society in Vietnam. Berkeley: University of California Press.

Qouta, Samir, Raija-Leena Punamäki, and Eyad El Sarraj. 2003. "Prevalence and Determinants of PTSD among Palestinian Children Exposed to Military Violence." European Child \& Adolescent Psychiatry 12(6): 265-72.

Qumsiyeh, Mazin B. 2011. Popular Resistance in Palestine: A History of Hope and Emowerment. London: Pluto Press. 
Rao, Hayagreeva, and Sunasir Dutta. 2012. "Free Spaces as Organizational Weapons of the Weak: Religious Festivals and Regimental Mutinies in the 1857 Bengal Native Army." Administrative Science Quarterly 57(4): 625-68.

Reicher, Stephen, Clare Cassidy, Ingrid Wolpert, Nick Hopkins, and Mark Levine. 2006. "Saving Bulgaria's Jews: An Analysis of Social Identity and the Mobilisation of Social Solidarity." European Journal of Social Psychology 36(1): 49-72.

Richter-Devroe, Sophie. 2011. "Palestinian Women's Everyday Resistance: Between Normality and Normalisation." Journal of International Women's Studies 12(2): 32-46

- 2018. Women's Political Activism in Palestine: Peacebuilding, Resistance, and Survival. Champaign: University of Illinois Press.

Ricks, Thomas M. 2006. "In Their Own Voices: Palestinian High School Girls and Their Memories of the Intifadas and Nonviolent Resistance to Israeli Occupation, 1987 to 2004. NWSA Journal 18(3): 88-103.

Roth, Susan, and Lawrence J. Cohen. 1986. "Approach, Avoidance, and Coping with Stress." American Psychologist 41(7): 813-19.

Rothermund, Klaus. 2003. "Automatic Vigilance for Task-Related Information: Perseverance after Failure and Inhibition after Success." Memory \& Cognition 31 (3): 343-52.

Rowbotham, Sheila. 1998. "Weapons of the Weak. Homeworkers' Networking in Europe." European Journal of Women's Studies 5(3-4): 453-63.

Saarela, Miiamaaria V., Yevhen Hlushchuk, Amanda C. de C. Williams, Martin Schürmann, Eija Kalso, and Riitta Hari. 2007. "The Compassionate Brain: Humans Detect Intensity of Pain from Another's Face." Cerebral Cortex 17(1): 230-37.

Schock, Kurt. 2005. Unarmed Insurrections: People Power Movements in Nondemocracies. Minneapolis: University of Minnesota Press.

Schulte-Rüther, Martin, Hans J. Markowitsch, Gereon R. Fink, and Martina Piefke. 2007. "Mirror Neuron and Theory of Mind Mechanisms Involved in Face-to-Face Interactions: A Functional Magnetic Resonance Imaging Approach to Empathy." Journal of Cognitive Neuroscience 19(8): 1354-72.

Scott, James C. 1985. Weapons of the Weak. Everyday Forms of Peasant Resistance. New Haven, CT: Yale University Press.

- 1987. "Resistance Without Protest and Without Organization: Peasant Opposition to the Islamic Zakat and the Christian Tithe." Comparative Studies in Society and History 29(3): 417-52.

-1990. Domination and the Arts of Resistance: Hidden Transcripts. New Haven, CT: Yale University Press.
Sharoni, Simona. 1995. Gender and the Israeli-Palestinian Conflict: The Politics of Women's Resistance. Syracuse, NY: Syracuse University Press.

Sharp, Gene. 1973. The Politics of Nonviolent Action. Boston: P. Sargent Publisher.

Sharp, Gene, and Afif Safieh. 1987. "Gene Sharp: Nonviolent Struggle.” Journal of Palestine Studies 17(1): 37-55.

Shikaki, Khali. 2006. "Willing to Compromise: Palestinian Public Opinion and the Peace Process" United States Institute of Peace, Research Report. Retrieved April 2, 2020 (https://www.usip.org/ publications/2006/01/willing-compromisepalestinian-public-opinion-and-peace-process).

Siegman, Jeremy A. 2020. "Playing with Antagonists: The Politics of Humor in Israeli-Palestinian Market Encounters." Political and Legal Anthropology Review 43 (1): 103-19.

Simon, Bernd, and Bert Klandermans. 2001. "Politicized Collective Identity: A Social Psychological Analysis." American Psychologist 56(4): 319-31.

Skinner Ellen A., Kathleen Edge, Jeffrey Altman, and Sherwood Hayley Sherwood. 2003. "Searching for the Structure of Coping: A Review and Critique of Category Systems for Classifying Ways of Coping." Psychological Bulletin 129(2): 216-69

Sorensen, Majken Jul. 2008. "Humour as a Serious Strategy of Nonviolent Resistance to Oppression.” Peace \& Change 33(2): 167-90.

Spradley, James P. 1979. The Ethnographic Interview. Long Grove, IL: Waveland Press.

Stewart, Andrew L., Felicia Pratto, Fouad Bou Zeineddine, Joseph Sweetman, Véronique Eicher, Laurent Licata, Davide Morselli, Rim Saab, Antonio Aiello, Xenia Chryssochoou, and Alecksandra Cichocka. 2016. "International Support for the Arab Uprisings: Understanding Sympathetic Collective Action Using Theories of Social Dominance and Social Identity." Group Processes \& Intergroup Relations 19(1): 6-26.

Strauss, Anselm, and Juliet Corbin. 1990. Basics of Qualitative Research. New York: Sage.

Sullivan, Sian. 2003. "Dissent or Libel in Resistance to a Conservancy in North-West Namibia." In Ethnographies of Conservation: Environmentalism and the Distribution of Privilege, ed. David G. Anderson and Eeva Berglund, 69-86. Oxford: Berghahn.

Sverke, Magnus, and Johnny Hellgren. 2001. "Exit, Voice and Loyalty Reactions to Job Insecurity in Sweden: Do Unionized and Non-Unionized Employees Differ?" British Journal of Industrial Relations 39(2): 167-82.

Szalontai, Balázs, and Changyong Choi. 2014. "Immunity to Resistance? State-Society Relations and Political Stability in North Korea in a Comparative Perspective." North Korean Review 10(1): 55-70. 
Tilly, Charles. 2003. The Politics of Collective Violence. Cambridge: Cambridge University Press.

Tsai, Wen-Hsuan, and Zheng-Wei Lin. 2019. "Social Constructionism and the Significance of Political Rumors in Contemporary China: Weapons of the Weak." Asian Survey 59(5): 870-88.

Van Troost, Dunya, Jacquelien Van Stekelenburg, and Bert Klandermans. 2013. "Emotions of Protest." In Emotions in Politics, ed. Nicolas Demertzis, 186-203. London: Palgrave Macmillan.

Van Zomeren, Martijn, Tom Postmes, and Russell Spears. 2008. "Toward an Integrative Social Identity Model of Collective Action: A Quantitative Research Synthesis of Three Socio-Psychological Perspectives." Psychological Bulletin 134(4): 504-35.

Veracini, Lorenzo. 2013. "The Other Shift: Settler Colonialism, Israel, and the Occupation." Journal of Palestine Studies 42(2): 26-42.

Vinthagen, Stellan, and Anna Johansson. 2013. "Everyday Resistance: Exploration of a Concept and Its Theories." Resistance Studies Magazine 1(1): 1-46.

Wade, Allan. 1997. "Small Acts of Living: Everyday

Resistance to Violence and Other Forms of Oppression." Contemporary Family Therapy 19(1): 23-39.

Weaver, R. Kent. 1986. "The Politics of Blame Avoidance." Journal of Public Policy 6(4): 371-98.

Wedeen, Lisa. 1999. Ambiguities of Domination: Politics, Rhetoric, and Symbols in Contemporary Syria. Chicago: University of Chicago Press.

- 2019. Authoritarian Apprehensions. Chicago: University of Chicago Press.

Weiss, Jessica Chen. 2013. "Authoritarian Signaling, Mass Audiences, and Nationalist Protest in China." International Organization 67(1): 1-35.
Weyland, Kurt. 2012. "The Arab Spring: Why the Surprising Similarities with the Revolutionary Wave of 1848?" Perspectives on Politics 10(4): 917-34.

White, Rachel E., Emily O. Prager, Catherine Schaefer, Ethan Kross, Angela L. Duckworth, and Stephanie M. Carlson. 2017. "The 'Batman Effect:' Improving Perseverance in Young Children." Child Development 88(5): 1563-71.

White House. 2020. "Peace to Prosperity." Retrieved April 1, 2020 (https://www.whitehouse.gov/wpcontent/uploads/2020/01/Peace-to-Prosperity0120.pdf).

Williams, Lisa A., and David DeSteno. 2008. "Pride and Perseverance: The Motivational Role of Pride." Journal of Personality and Social Psychology 94(6): 1007-17.

Wilson, Richard Ashby, and Richard D. Brown, eds. 2008. Humanitarianism and Suffering: The Mobilization of Empathy. Cambridge: Cambridge University Press.

Wolford, Scott. 2014. "Showing Restraint, Signaling Resolve: Coalitions, Cooperation, and Crisis Bargaining." American Journal of Political Science 58(1): 144-56.

Wood, Elisabeth J. 2003. Insurgent Collective Action and Civil War in El Salvador. Cambridge: Cambridge University Press.

World Bank. 2019a. "Palestine's Economic UpdateOctober 2019.” Retrieved April 1, 2020 (https:// www.worldbank.org/en/country/westbankandgaza/ publication/economic-update-october-2019). . 2019b. "Palestinian Territories." Retrieved April 1, 2020. (http://pubdocs.worldbank.org/ en/250361570664056483/EN-MPO-OCT19Palestine.pdf).

Yom, Sean L., and F. Gregory Gause III. 2012. "Resilient Royals: How Arab Monarchies Hang On." Journal of Democracy 23(4): 74-88. 